\title{
Yod
}

Revue des études hébraïques et juives

19 | 2014

Aharon Appelfeld, cinquante ans d'écriture

\section{A Journey to Poland - A Return to the Self in Poland, a Green Country by Aharon Appelfeld}

Un voyage vers la Pologne - un retour vers soi

המסע לפולין כחזרה אל האני

\section{Shoshana Ronen}

\section{OpenEdition}

Journals

Electronic version

URL: https://journals.openedition.org/yod/2043

DOI: $10.4000 /$ yod.2043

ISSN: 2261-0200

\section{Publisher}

INALCO

Printed version

Date of publication: 30 May 2014

ISBN: 978-2-85831-214-6

ISSN: 0338-9316

\section{Electronic reference}

Shoshana Ronen, "A Journey to Poland - A Return to the Self in Poland, a Green Country by Aharon Appelfeld", Yod [Online], 19 | 2014, Online since 16 April 2014, connection on 08 July 2021. URL: http:// journals.openedition.org/yod/2043 ; DOI: https://doi.org/10.4000/yod.2043

This text was automatically generated on 8 July 2021.

\section{(c) (†) 8}

Yod est mis à disposition selon les termes de la Licence Creative Commons Attribution - Pas d'Utilisation Commerciale 4.0 International. 


\title{
A Journey to Poland - A Return to the Self in Poland, a Green Country by Aharon Appelfeld
}

Un voyage vers la Pologne - un retour vers soi

המסע לפולין כחזרה אל האני

\author{
Shoshana Ronen
}

1 Poland, a Green Country can be read in different ways. ${ }^{1}$ A story of the mid-life crisis of Jacob Fein, a typical Israeli sabra, can be read as yet another link in the long chain of journeys to Poland in Hebrew literature; ${ }^{2}$ it can also be read as a love story, or as a story of an encounter between Jews and Poles. ${ }^{3}$ In gender-oriented reading, it would be interesting to contrast the two main female characters: Jacob's wife-dry, calculated, practical and egoistical; and Magda-a loving, devoted and altruistic mother-nature figure.

2 In this paper, however, I would like to propose another reading as a tale of teshuvarepentance. ${ }^{4}$ Jacob's journey, which is a pilgrimage of atonement, contains the two meanings of the Jewish concept teshuva: שיבה means a return-coming back to the sources, to the point of origin, as well as להשיב means to respond or to reply-a response to a call, originally from the divine; a reply to God's command. Teshuva is an act of contrition for sins and transgressions, mostly, when a Jew detached himself from God and the people of Israel. The idea of a covenant between God and man is central in Jewish religion. When man sins he violets the covenant and only remorse, and spiritual and ethical self-purification can bring forgiveness and restore the covenant. Teshuva, then, has the two dimensions: a return to the strait path, to the place of origin, to an ideal state of harmony between man and God, between a Jew and Israel, and a response to a divine call. This call may be transcendent, from God, or internal from inside man's soul. The call awakes the will to mend the damage, or the disgrace.

In Appelfeld's novel the return to the foundation, to the origin, and the response to the call is a response not to God's command, but to the appeal of Jacob's ancestors, the call 
of past generations, and, in fact, the call of the hidden, perhaps still unconscious self. This self feels a void; it is alienated from its identity, from its ancestors, from its origin. Jacob's teshuva has the goal of mending the tear between his present life and his past. Without it he will be like a wellspring whose source is blocked and therefore is doomed to dry out. Jacob's journey, more than a movement in space, is an inner transformation of the soul, a revelation of an authentic identity. ${ }^{5}$

Jacob Fein, a successful businessman and ex-officer in the Israeli army, can be grasped as a prototype of the average Israeli. His first name, Jacob, as the name of the patriarch Jacob-Israel, alludes to him potentially being perceived as a typical Israeli, a warrior, tough, and persistent. Feeling emptiness in his life and a lack of communication with his wife and daughters, Jacob decides to embark on a journey to Poland. He wants to see the village where his parents lived before the war. In mid-life he becomes determined to fulfill this desire, to go to Shidowce, which had been growing in him over the last few years. For years he had felt discomfort and wished to escape his life and family, but he was not aware of the source of this uneasiness until waking up one night with a decision to visit his parents' village. Although he can't give a reasonable explanation for this need, he acknowledges that some things are beyond reason and that "sometimes one has to response to the caprice of the heart" (p. 9). Jacob hears a call, and the need to respond lies in the emotional layer of his existence and not the rational. This is the beginning of his teshuva. Reading further we can comprehend the source of his discomfort: a sin that requires repentance. In order to understand his impulse, to have the right conditions for reflection and for the process of purifying his heart and his awareness, he has to leave his home, to acquire distance which will allow the necessary perspective. The physical change of location will bring about a change in his personality and identity, a journey into his true self. In the end he will discover his roots and place of origin and with it, his new old identity.

5 The journey in Appelfeld's novel is unique. As Yigal Schwartz showed: "The main characters in some of Appelfeld' journey stories do not reach their destination, while in others they do but fail to recognize it or connect with it." ${ }^{1}$ However, in Poland, a Green Country Appelfeld illustrates a different journey. The main protagonist not only reaches the destination, but, in addition, the result of his pilgrimage is an atonement for his past sins and a mental and spiritual transformation. This journey is not as in Schwartz words "a journey to eternal exile", 7 but a journey that ends in coming home. Referring to other works by Appelfeld, Sidra DeKoven-Ezrahi claimed that '"Return' in an Appelfeld story is a gesture not so much of 'going back' as of 'repeating'-and writing the return remained as obsessive and incomplete as the act itself". ${ }^{8}$ Yet, in Poland, a Green Country the return is real.

6 Repentance is needed when a sin is committed or in the event of a deviation from the right path. So, what was Jacob's sin?

7 Since early on Jacob felt that his parents were different. He saw them as strangers, incomprehensible, simple villagers, introverts, silent, narrow-minded, dull, forlorn and lifeless. When Jacob was a young boy his mother used to tell him about their life during the war, but to hold the little child's attention she told it as an adventure story, as a game of hide-and-seek. Though, while very young, Jacob liked to listen to these stories, he lost interest when he was around twelve. Other things were much more exiting then: friends, school, youth movements, football, girls (p. 36). The ultimate rebellion came when he was thirteen: "All the clichés he absorbed at school he uttered at home 
with an infantile arrogance" (p. 36), and refused to have his Bar Mitzvah ceremony. His parents failed to confront him and gave up, letting him go his own way, and never again told him about their life experiences.

8 This generational conflict can be understood as the contradiction between the old Jew and the New Hebrew-the Israeli who despises the diasporic Jew. Jacob felt superior, he was critical towards his parents, and they accepted it without complaint. "You are the winner, the talented, the future, we are mortal" (p.16) his mother used to say and Jacob was sure "that there is nothing in their life which can excite him. Their life seemed to him loaded with agony and full with sad memories. Their death has not changed the alienation he felt towards them. Only a feeling of guilt was added" (p. 72). The culmination of Jacob's rejection of his parents was the total liquidation of their home and belongings after their death. A month after his mother's death he sold the house and gave away its contents to a charity that emptied the house of all its objects in a mere two hours. He did not leave a thing, not even a small keepsake for himself. Not the candlesticks, not the prayer shawl and the phylacteries, not even the prayer book. He wiped out the memory of his parents' life, and left no trace of the traditional religious Jewish way of being (p. 189). Jacob's sin was his total indifference towards his parents, his absolute rejections of them. He felt contempt towards their life, their tradition, their longing for their homeland in the diaspora, for Shidowce. Jacob's attempt to erase completely his parents' memory was the final act of disrespect to their home and belongings after their death.

9 The call for repentance comes at nights, in Jacob's dreams. In mid-life, after years without dreaming, his nights gradually become interrupted by recurring nightmares. His mother appears time and again, and in contrast to her silence in life, she is very talkative in the dreams, telling him about her experiences during the war, about life in the village, about the destruction. At first, Jacob resists and tries to elude the dreams but they stubbornly return night after night till he feels his life splitting in two: his normal daily routine and his sleep life. He decides, or perhaps is forced, to answer the call. It is much more than a rational decision, but rather a compulsory urge and this is why he resolves to travel to Poland.

10 Jacob's repentance requires a voyage which will become a return-a return to his authentic self. He leaves his home and family and goes on a journey to Shidowce in order to find that his true home is in a small village in Poland. After his parents' death he erased their home and their memory, but in Shidowce he is able to regain this memory anew. The journey is a pilgrimage of atonement for the act of obliterating the memory of his parents.

11 Avi Sagi suggested that Poland, a Green Country has metaphysical elements. "The biographic journey in a literary work is a journey into metaphysics, which must begin with personal datum. This datum contains in its deepest levels, the writer's 'secrets of the soul and fate', but not only his. After all, the nature of metaphysics is that it cannot be personal." In my opinion, the term "metaphysical" is inadequate because Jacob's response is to a call from his ancestors and not from a divine force. Consequently, we do not observe transcendence in this story but only the human sphere with its complexities and varieties of existential choices. Therefore, and here I do agree with Sagi, we have an existential story. ${ }^{10}$ The journey will confer upon him a sense of his life, will change his consciousness and identity, will connect him with his roots and his true self. 
12 From the first moment in Poland, Jacob feels at home. The place is not strange but familiar. Already on his first day there, on the train from Warsaw to Krakow, he feels himself being severed from his previous life and Tel Aviv begins to seem unreal (pp. 12, 88). In Krakow he feels that he is standing on the threshold of a world which had been hidden latent inside him (p. 22). As Jacobs says "a place does not reveal, but only what a person brings within himself" (p. 32). Jacobs feels at home at once and even the Polish language becomes familiar (pp. 47-48).

13 Yet, the most important role in Jacob's process of teshuva belongs to the Polish peasant woman Magda. Magda knew Jacob's parents before the war. As a child she was a domestic worker in his grandparents' house and throughout the long passing years she has cherished the memories of the lost Jewish world in Shidowce with love and admiration. She transfers this knowledge and love to Jacob, and imparts her memories to him. Magda-a gentile woman-enables him to go through a transformation. She serves as a medium to connect him with his parents and their world; she is the carrier of the Jewish memory. She tells him about the Jewish customs in his parents' house: their way of life, what they did, what they dreamt of, how they dressed, about their secrets, and about her love for them (pp. 66-67, 73). In accordance with Terence saying "I am human, I consider nothing human alien to me", ${ }_{11}^{11}$ Magda tells Jacob: "nothing Jewish is alien to me, my body is full of Jewish words and melodies" (p. 69). Jacobs feels that Magda has the key to the mysterious world of his parents, to which she is going to introduce him (p.68). Thanks to her, he feels himself regaining the memory of his parents which he had successfully erased. He finally begins to know and respect them: "I did not understand my parents. They seemed to be unrelated to my life" (p. 192). But with Magda's help he perceives his parents as dignified and human. In Shidowce he learns to understand that he has ancestors who live inside him (p. 201), and thanks to Magda he finally recognizes that their world was much wider than his. Once he thought of them as narrow-minded but he eventually realizes that in their life they touched on the deep mystery of the soul (p. 131). The Polish woman endows him with his identity, reconnects him to his past and family, fills the void in his soul and teaches him to love his parents.

Nevertheless, Magda also tells him about the horrors of the war and the atrocities done to Jews, and about the still-persisting and many-faceted hostility of Polish people towards Jews (pp. 136-137). But he trusts her and feels secure: she will protect him. He dreams that he is attacked by peasants but Magda-clearly presented as Mary Magdalene-rescues him. The crowd accuses her of being a prostitute, whereas in fact, she is a saint who protects him (p. 158). In his pilgrimage of atonement Jacob meets a Polish saint woman who saves his life. In the dream she saves his body, but in reality it is his soul that is saved.

15 Yet, this idyll cannot last forever. Although he feels at home, and in spite of Magda's love and care, he has to leave. The anti-Semitism of the Polish peasants, their hostility towards and fear of Jews compel him to return, to understand that this home cannot be his home. However, he returns a different man (pp. 118-119). Magda, who introduced him to his parents' world, made him value and love what before he had despised. Due to the process of teshuva Jacob is aware of the rich, valuable and fascinating world of his parents, and he carries within himself love and appreciation towards them instead of the contempt he felt previously. Dreams are constantly a very important component in his inner life and in one of them he declares: "I return home full of appreciation for my 
ancestors who knew how to struggle with the place's wilderness, I did not know how to love them. Now I have learnt to love them" (p.154). In another dream he tires to convince his daughter how essential the journey was: "I return a different person. [...] many years I have lived in self deception. Now is the time to go out of the cave" (p. 152). As in Plato's cave allegory, ${ }^{12}$ till now he was living in delusion, perceiving shadows as reality, but the journey made him see his parents' real life clearly. Shidowce and Magda, like the sun in Plato's cave allegory, enable him to understand what had been hidden from him for years.

The teshuva, the return to his authentic self is, in fact, the change in his attitude towards his parents. He starts to understand them. They turn, in his eyes, into full, interesting, dignified human figures. They become round, complex characters. The abounding world of his parents enriches him, completes what he had lacked, what had caused his restlessness for years.

17 At the end of the journey Jacob reaches repentance, but does he also attain salvation? Shortly after leaving Shidowce he already feels that he has lost the secret Magda entrusted to him, the Agnonic key ${ }^{13}$ to the lost world (p. 206). When a companion on the flight asks him what he found, his immediate and spontaneous answer is "nothing" (p. 214) and he is terrified by this answer. Is it possible that he instantly forgot what he found in Shidowce, and that what was so meaningful a day before has just disappeared? Or, perhaps, the process of his self-transfiguration cannot be uttered in words?

The man on the flight back tells Jacob that the rich, deep green of the Polish soil drives one crazy; it hides the Jewish cemeteries and the past. The beautiful title of the book turns out to be ironic; the green country is not beautiful but deceiving. ${ }^{14}$

It seems that the journey which brought Jacob back to his true origin and identity, and the process of repentance, is only the beginning of full atonement. The story ends with the words "only the person who returns to his ancestors' village is permitted to ask for their forgiveness". Avi Sagi understands these words as follows: asking for forgiveness without self-transformation is empty. ${ }^{15}$ Only a full assimilation of the ancestors' heritage enables forgiveness. Jacob is now in the position of being permitted to ask for forgiveness. Jacob-the new Israeli-can find repentance only by assimilating the old Jewish diasporic world within himself.

\section{BIBLIOGRAPHY}

DEKOVEN-EZRAHI, Sidra (2005). “The Jewish Journey in the Late Fiction of Aharon Appelfeld: Return. Repair or Repetition”, Mikan, vol. 5, January 2005.

KURZWEIL, Baruch (1966), מסות על סיפורי ש"י עגנון ("Essays on S.Y. Agnon's Stories”), Schocken, Tel Aviv.

NAVEH, Hannah (2002), בספרות העברית החדשהנוסעים ונוסעות - סיפורי מסע"Men and Women Travellers: Travel Narratives in Modern Hebrew Literature"), Ministry of Defence, Israel. 
PLATO, The Republic, Book VII.

RONEN, Shoshana (2007). Polin - A Land of Forests and Rivers: Images of Poland and Poles in Contemporary Hebrew Literature in Israel. WUW, Warsaw.

SAGI, Avi (2011). "פולין ארץ ירוקה - מניכור לזהות" ("Poland a Green Country - From Alienation to Identity”) in SAGI, Avi \& LIPSKER, Avidov (eds.), קריאות בכתבי אהרן אפלפלד ("24 Readings in Aharon Appelfeld's Works"), Bar-Ilan University, Ramat-Gan.

SCHWARTZ, Yigal (2001). Aharon Appelfeld: From Individual Lament to Tribal Eternity, Brandeis University Press, Hanover \& London.

\section{NOTES}

1. Aharon Appelfeld (2005), פולין ארץ ירוקה ("Poland, a Green Country”), Jerusalem, Keter (Hebrew). There is no English translation of this novel, so all the quotations are my translation.

2. See: Shoshana Ronen (2007), Polin - A Land of Forests and Rivers: Images of Poland and Poles in Contemporary Hebrew Literature in Israel. WUW, Warsaw.

3. Sh. Ronen (2007), pp. 165-182.

4. More about Teshuva see: Ehud Luz (2009) "Repentance", in Arthur Cohen \& Paul Mendes-Flohr (eds.), 20th Century Jewish Religious Thought, JPS, Philadelphia, pp. 785-793.

5. On journeys as a certain pattern in literature to articulate mental and psychological change see: Hannah Naveh (2002), בספרות העברית החדשה נוסעים ונוסעות - סיפורי מסע ("Men and Women Travellers: Travel Narratives in Modern Hebrew Literature"), Ministry of Defence, Israel, p. 123.

6. Yigal Schwartz (2001). Aharon Appelfeld: From Individual Lament to Tribal Eternity, Brandeis University Press, Hanover \& London, p. 73.

7. Y. Schwartz (2001), p. 74.

8. Sidra DeKoven-Ezrahi (2005). "The Jewish Journey in the Late Fiction of Aharon Appelfeld: Return. Repair or Repetition", Mikan, vol. 5, January 2005, p. 50.

9. Avi Sagi (2011), "פולין ארץ ירוקה - מניכור לזהות" ("Poland a Green Country - From Alienation to Identity”) in Avi Sagi \& Avidov Lipsker (eds.), קריאות בכתבי אהרן אפלפלד ("24 Readings in Aharon Appelfeld's Works"), Bar-Ilan University, Ramat-Gan p. 242.

10. Ibid.

11. "Homo sum: humani nil a me alienum puto", Terence (Publius Terentius Afer), Heauton Timorumenos (The Self-Tormentor), Actus I (act I), Scaena I (scene I).

12. Plato, The Republic, Book VII.

13. Agnon's A Gust for the Night is also a tale of a late return to once homeland, which does not exist anymore. The narrator loses the key of the old Yeshiva in Buczacz, which he received for custody, and then, surprisingly, finds it when he is already in Eretz Israel. The key is a symbol for the power over the old world. The narrator has the key-the password, the code, to open the door of the old homeland. Only that, like in Agnon novel, this world was vanished and the key is lost. Jacob lost the secret Magda entrusted to him, a key which enabled him to understand his parents' world. More about the meaning of "key" in Agnon's works see: Baruch Kurzweil (1966), מסות על סיפורי ש"י עגנון ("Essays on S.Y. Agnon's Stories”), Schocken, Tel Aviv, pp. 54-68.

14. The deception of the green fields that cover the Jewish past in the Polish land reminds the woods in A.B. Yehoshua's story "Facing the Forests". In this story a beautiful green and newly planted forest hides an Arab village, which was located in the place before 1948 war. This village was destroyed by the Israelis and covered with beautiful green trees. In Yehoshua's story, the forest goes up in flames and the remnants of the village are exposed. 
15. A. Sagi (2011) p. 258.

\section{ABSTRACTS}

In his mid-life Jacob Fein, a businessman, an ex-officer in the Israeli army, unhappily married, and a failed father of two daughters, embarks on a Journey to the birthplace of his parentsHolocaust survivors-to a small village not far from Krakow. It was a sudden decision, in fact not a decision but an impulsive urge. The journey turns into a pilgrimage of atonement. Jacob, who in his youth made a great effort in order to move away from his parents and their world, to detach himself from the Jewish past and his roots, feels his life hollow. In the journey he becomes acquainted with his parents' life before the war, with their world, habits, beliefs, and their green and wild environment. The nature there, so different from Tel-Aviv, enchants him. His parents and ancestors, who were in his eyes wretched and miserable, become worthy, full, interesting, and dignified. The world of his parents fills the hollowness of his life and his self. The self which, as he comes to understand in the village, is incomplete and blemished without the past. Perhaps reconciling with the parents is not enough for a complete atonement, but at the end of the Journey Jacob is in a state in which he is allowed to ask for forgiveness.

Jacob Fein, homme d'affaires, ancien officier de l'armée israélienne, malheureux en couple et père de deux filles, entreprend un voyage vers le lieu de naissance de ses parents rescapés de la Shoah, un petit village non loin de Cracovie. Ce fut une décision soudaine ou plus exactement une furieuse envie. Ce voyage se transforme en pèlerinage. Jacob, qui dans sa jeunesse avait tout fait pour s'éloigner de ses parents et de leur univers, pour se détacher de son passé juif et de ses racines, ressent un vide dans sa vie. Pendant ce voyage, il prend connaissance de la vie de ses parents avant la guerre, de leur monde, de leurs coutumes et de leurs croyances, ainsi que de la nature sauvage qui les entourait. La nature surtout, si différente de Tel Aviv, l'enchante. Ses parents et ses ancêtres, qu'il voyait auparavant comme des êtres malheureux et misérables, deviennent estimables, attachants, dignes. Le monde de ses parents comble son vide intérieur. Dans ce village, il arrive à comprendre que, sans ce passé, sa vie est incomplète, imparfaite. La réconciliation avec ses parents n'équivaut peut-être pas à une véritable contrition, mais à la fin de ce voyage, il peut envisager le pardon.

יעקב פיין, איש עסקים, קצין לשעבר בצה"ל, אב לשתי בנות ואינו מאושר בנישואיו, יוצא למסע

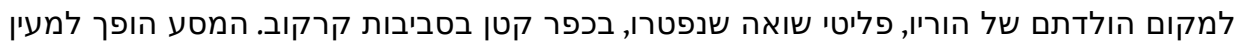

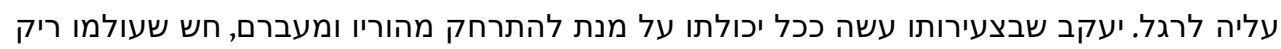

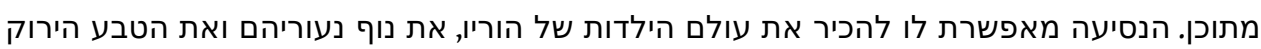

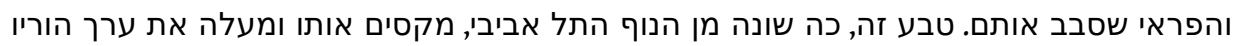

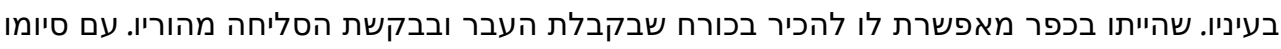
של המסע תהליך בקשת הסליחה יכול להתחיל. 
INDEX

אפלפלד, הדור השני, פולין, תשובה, פולין ארץ ירוקהמילות מפתח:

Mots-clés: Appelfeld Aharon (1932-), deuxième génération, contrition, Pologne terre verte

Keywords: Appelfeld Aharon (1932-), second generation, Poland, Holocaust, atonement, Poland a Green Country, literature

Subjects: littérature

Geographical index: Pologne

Chronological index: Shoah

\section{AUTHOR}

\section{SHOSHANA RONEN}

University of Warsaw 